Agnieszka Kłos

\title{
SYSTEM FINANSOWANIA PROGRAMÓW OPERACYJNYCH W POLSCE - IMPLIKACJE DLA STANU FINANSÓW PUBLICZNYCH'
}

\section{Wprowadzenie}

W okresie kryzysu gospodarczego pojawiają się przed Unią Europejską coraz większe wyzwania dotyczące realizacji polityki strukturalnej oraz polityki spójności. Problem finansowania rozwoju regionalnego dotyczy nie tylko organów Unii Europejskiej, przygotowujących plany budżetu Unii Europejskiej w sytuacji zwiększających się potrzeb finansowych, ale także poszczególnych krajów członkowskich, które zmagają się z wysokimi miernikami stanu finansów publicznych, tj. długu publicznego i deficytu budżetowego. Zdaniem autorki problem finansowania rozwoju regionalnego zasługuje na szczególną uwagę nie tylko we współczesnej myśli ekonomicznej, lecz także w praktycznym aspekcie funkcjonowania systemu finansowania programów operacyjnych realizowanych ze środków publicznych, w tym środków pochodzących z funduszy strukturalnych Unii Europejskiej. Jest on szczególnie istotny w chwili obecnej ze względu na niepokojący w Polsce poziom długu publicznego oraz deficytu budżetu państwa i próby równoważenia finansów publicznych, ale także z uwagi na rozpoczynające się negocjacje na temat kształtu polityki regionalnej UE i jej finansowania w nadchodzącym nowym okresie programowania 2014-2020. Aktualne są wciąż rozważania nad wykorzystaniem nowych metod i instrumentów zarządzania finansami publicznymi w walce ze wzrastającym poziomem ww. wielkości makroekonomicznych, tj. długu publicznego i deficytu budżetu, nie tylko w Polsce, ale także w skali międzynarodowej. Wszelkie działania służące poprawie stanu finansów publicznych stanowią jeden ze strategicznych celów podejmowanych przez władze publiczne. Problem ten jest szczególnie istotny również dlatego, że obowiązują Polskę, jako kraj aspirujący do wejścia do strefy euro, kryteria

\footnotetext{
1 Niniejsze opracowanie jest wersją skróconą publikacji, która ukazała się w języku angielskim w numerze 4 ,Warsaw Forum of Economic Sociology”. Wersja publikacji w języku angielskim zawiera szerszy przegląd teorii długu publicznego i deficytu budżetowego oraz w części badawczej obszerną analizę finansową mierników stanu finansów publicznych wraz z tabelami finansowymi.
} 
konwergencji, tj. utrzymanie długu publicznego na poziomie nie wyższym niż $60 \%$ PKB oraz utrzymanie deficytu budżetu państwa na poziomie nie wyższym niż 3\%.

Przedmiotem badań dyscyplin nauki z zakresu rozwoju społeczno-gospodarczego, rozwoju regionalnego jest m.in. analiza rodzajów i zakres wykorzystania funduszy strukturalnych Unii Europejskiej oraz ocena skwantyfikowanych wskaźników, np. wartość zrealizowanych projektów, poziom bezrobocia, wzrost zatrudnienia, liczba wybudowanych autostrad, dróg szybkiego ruchu, powstałych przedszkoli, szkół itp., które świadczyłyby o wzroście potencjału gospodarczego danego regionu. Są to cenne badania poznawcze, mające na celu wykazanie praktycznego powiązania wykorzystania środków pochodzących z funduszy strukturalnych Unii Europejskiej ze wzrostem poziomu gospodarczego i konkurencyjności regionów. Jednakże w formułowaniu wniosków dotyczących wielkości wydatków i ich przełożenia na wielkość wskaźników, określających zmiany w rozwoju regionalnym, brak jest badań wykazujących powiązanie wydatków przeznaczonych na realizację polityki regionalnej z ich oddziaływaniem na mierniki makroekonomiczne finansów publicznych, tj. dług publiczny oraz deficyt budżetu państwa. Podobnie w dyscyplinie nauk z zakresu finansów publicznych brak badań analizy oddziaływania wydatków przeznaczonych na realizację programów operacyjnych finansowanych ze środków publicznych Unii Europejskiej na ww. mierniki finansów publicznych. Problem ten $\mathrm{w}$ dyscyplinie nauki finansów publicznych zasługuje szczególnie na uwagę chociażby ze względu na to, że od chwili wstąpienia Polski w struktury Unii Europejskiej środki pochodzące z budżetu Unii Europejskiej, z funduszy strukturalnych stały się integralną częścią systemu finansów publicznych oraz budżetu państwa.

W opracowaniu autorka w sposób syntetyczny przedstawia ocenę oddziaływania systemu finansowania programów operacyjnych realizowanych w Polsce w ramach perspektyw finansowych Unii Europejskiej 2000-2006 oraz 2007-2013 na wielkość mierników kondycji sektora finansów publicznych, tj. dług publiczny i deficyt budżetu państwa.

\section{Przegląd wybranych teorii długu publicznego i deficytu budżetowego}

Przedstawiony przegląd teorii finansów publicznych jest podyktowany tym, że odgrywały one znaczącą rolę w praktycznym posługiwaniu się finansami publicznymi. Teorie te były i są podstawą polityki państwa w zakresie nakładania ciężarów podatkowych oraz w zakresie wydatkowania publicznego. Problematyka długu 
publicznego w sensie teoretycznym stanowi element ogólnej teorii ekonomicznej i znalazła odzwierciedlenie w teorii finansów publicznych.

Teoretyczne podstawy liberalizmu gospodarczego stworzył A. Smith w XVIII wieku. W dziele Badania nad natura i przyczynami bogactwa narodów ostatnią, piątą księgę poświęcił finansom publicznym² ${ }^{2}$ Był zwolennikiem teorii leseferyzmu, zgodnie z którą rząd powinien jak najmniej ingerować w działalność gospodarczą obywateli. W książce The Wealth of Nations zawarł główne tezy liberalnej myśli ekonomicznej. Zgodnie z nimi rola państwa w gospodarce, a tym samym jego wydatki publiczne powinny zostać zminimalizowane tylko do podstawowych funkcji, tj. obrona zewnętrzna, ochrona własności i wymiar sprawiedliwości, organizacja robót publicznych, a budżet państwa powinien być jak najmniejszy ${ }^{3}$. Był zwolennikiem ograniczania rządowych wydatków publicznych, a całe zło związane z zadłużeniem publicznym przypisywał niszczeniu kapitału za pomocą zadłużenia wygenerowanego, a nie samemu zadłużeniu. Teorię A. Smitha rozwijał D. Ricardo. Podkreślał, że jeżeli podatnicy żyjący w okresie tworzenia zadłużenia w pełni skapitalizują przyszłe płatności podatków, to spłata oprocentowania zadłużenia staje się jedynie zwykłym transferem, który nie pociąga za sobą jakiejkolwiek ofiary ze strony przyszłych pokoleń. W takiej sytuacji dług publiczny nie przenosi na przyszłość rzeczywistego kosztu wydatków rządowych ${ }^{4}$.

Zarówno A. Smith, jak i D. Ricardo stali na stanowisku, że finansowanie wydatków emisją długu pozwala na przesunięcie obciążeń związanych z wydatkami w czasie, do momentu zapadalności wyemitowanych zobowiązań. Koszty związane ze wzrostem obciążeń podatkowych niezbędnych do obsługi i spłaty zaciągniętego długu przenoszone były z pokolenia na pokolenie, na którym ciążył obowiązek spłaty tego zadłużenia. Zwracali uwagę, że w zależności od rodzaju wydatków finansowanych emisją długu, przyszłe pokolenie mogło być beneficjentem korzyści z nim związanych. Istniało jednak niebezpieczeństwo wystąpienia pokusy wśród bieżących podatników do nadmiernego zadłużania się̧.

Reprezentant klasycznej szkoły angielskiej J.S. Mill dowodził, że dług publiczny powoduje obciążenie, które jest przenoszone na przyszłość ze względu na podatki wymagane pod kątem obsługi długu' .

2 A. Smith, Badania nad natura i przyczynami bogactwa narodów, PWN, Warszawa 1954.

3 Z. Fedorowicz, Instytucje finansowe, PWE, Warszawa 1965, s. 161.

4 M. Poniatowicz, Dlug publiczny w systemie finansowym jednostek samorzadu terytorialnego (na przykładzie miast na prawach powiatu), Wydawnictwo Uniwersytetu w Białymstoku, Białystok 2005, s. 42.

${ }_{5}$ B. Jajko, Dług publiczny a równowaga fiskalna, czy i kiedy rząd powinien emitować dług publiczny?, CeDeWu, Warszawa 2008, s. 10-11.

${ }^{6}$ M. Poniatowicz, op.cit., s. 42; H.C. Adams, Public Debts: An Essey in the Sience of Finance, Ayer Company Publishers, 1975. 
W teoriach głoszonych przez przedstawicieli szkoły klasycznej doszukać się można wielu sprzeczności. Niektórzy opowiadali się za zrównoważeniem budżetu, niskimi obciążeniami społeczeństwa, ale jednocześnie wyznaczali państwu coraz większy zakres obowiązków, które wymagają zwiększenia wydatków publicznych. J. Tucker uważał, że realizacja doktryny liberalnej nie zwalnia państwa od działań prowadzenia prowzrostowej polityki, zapewnienia wysokiego zatrudnienia i ochrony rodzimej produkcji. D. Ricardo wyznaczył państwu dodatkowy szerszy zakres obowiązków, tj. likwidację barier w wymianie międzynarodowej ${ }^{7}$.

Gdy pojawia się luka dochodowa spowodowana wzrostem wydatków w stosunku do możliwych do osiągnięcia dochodów, konieczne jest podjęcie działań zmierzających do zmniejszenia niedoboru dochodów. Pojawia się konieczność do sięgnięcia do przychodów budżetowych, które mogą przybrać formę pożyczki zaciąganej w kraju lub za granicą. Wyjaśniając prawną i ekonomiczną istotę pożyczek zaciąganych przez rządy w celu sfinansowania tej części zadań państwa, na które nie ma pokrycia w bieżących dochodach budżetu, stosuje się zasadę kontrastu, porównując je z podatkami. Jedna $\mathrm{z}$ teorii głosi, że pożyczka, z uwagi na płacone odsetki, jest droższym sposobem niż podatek, w przypadku poboru którego zmniejszają się fundusze nabywcze podatników, ale obciążenia ponoszone przez państwo są mniejsze. Inna teoria zwraca uwagę na iluzoryczność dobrowolności i umowności pożyczki ze względu na narzucane przez państwo warunki umowy, bez możliwości ich negocjowania oraz wywieranie nacisku psychologicznego i materialnego pożyczkodawców przy zaciąganiu pożyczek. Teoria realistyczna zwraca uwagę na swoisty charakter pożyczki publicznej. Nie neguje całkowicie faktu wywierania nacisku psychologicznego. W myśl tej teorii trudno jest ten nacisk porównać z przymusem prawnym występującym w przypadku podatku ${ }^{8}$.

Ortodoksyjna doktryna finansów publicznych opierała się na założeniu, że rząd powinien ograniczać swoje wydatki do poziomu swoich przychodów podatkowych, czyli powinien równoważyć budżet ${ }^{9}$. Podwaliny tej doktryny stworzył J.B. Say. Uważał, że nadmierny wzrost wydatków przyczynia się do wzrostu stóp procentowych oraz zmniejszania wysokości płac i innych dochodów. W związku z tym budżet powinno się tworzyć tylko do takiej wysokości, która pozwala finansować niezbędne zadania publiczne państwa. Budżet powinien być zrównoważony, i to

${ }^{7}$ A. Moździerz, Nierównowaga finansów publicznych, PWE, Warszawa 2009, s. 15-19.

8 W. Gradoń, Deficyt budżetowy i źródła jego finansowania w Polsce, Wydawnictwo Akademii Ekonomicznej w Katowicach, Katowice 2004, s. 26-28; M. Krawczyk, O neutralności długu publicznego. Wokót ricardiańskiego teorematu ekwiwalentności - R. Barro, J. Tobin i inni, Oficyna Wydawnicza SGH, Warszawa 2007, s. 14-16.

${ }^{9}$ J. Zajda, Od budżetu fiskalnego do budżetu ekonomicznego w państwie kapitalistycznym, PTE, Poznań 1958, s. 165-166. 
w sposób trwały. Deficyt budżetowy oznaczał ryzyko bankructwa i był traktowany jako obciążenie przyszłych pokoleń ${ }^{10}$.

Według P.A. Samulesona, laureata Nagrody Nobla, finanse publiczne w teorii ortodoksyjnej były traktowane analogicznie jak finanse rodziny. Dług publiczny traktowano jako ciężar przyszłych pokoleń, należało więc go unikać ${ }^{11}$. W sytuacji, gdy nie można uniknąć długu publicznego, ortodoksyjni fiskaliści zalecali, aby pożyczki i kredyty przeznaczone zostały jedynie na cele inwestycyjne, wykorzystywane w ramach operacji długoterminowych oraz jak najszybciej spłacane, aby nie powiększać kosztów obsługi zadłużenia ${ }^{12}$.

Ważnym hasłem ortodoksyjnej teorii finansów publicznych było twierdzenie o określaniu jasnego źródła oraz przeznaczenia zaciąganych przez państwo pożyczek. Zwolennicy tej teorii uważali, że jeżeli nie da się uniknąć deficytu budżetowego, to musi być on bezwzględnie przeznaczany na finansowanie wydatków stymulujących rozwój gospodarczy. W przypadku, gdy istnieje konieczność zaciągnięcia pożyczki, powinna ona mieć charakter długoterminowy, tak aby nie zmniejszać kapitałów bieżących potrzebnych podmiotom prywatnym. Ortodoksyjny fiskalizm wykluczał możliwość wykorzystania podatków zbieranych przez państwo do innych celów niż czysto fiskalne, np. na opłacanie służb skarbowych, celnych oraz pozostałej obsługi administracyjnej ${ }^{13}$.

Próby rozwijania protekcjonistycznej polityki państwa podejmowali także uczeni niemieccy. Konieczność szerszej ingerencji państwa w mechanizm rynkowy postulował A. Wagner. Jemu przypisuje się autorstwo prawa wzrastających wydatków publicznych, tzw. prawo Wagnera. U podstaw koncepcji A. Wagnera leżało założenie, że mechanizm rynkowy jest ułomny, gdyż tworzy warunki do wynagradzania czynników produkcji, tj. ziemi, pracy i kapitału, ale nie jest w stanie zaspokoić rozwijających się potrzeb społecznych. Koniecznością jest zatem angażowanie się państwa w rozwiązywanie problemów społecznych ${ }^{14}$.

Zasługi A. Wagnera dla rozwoju nurtu interwencjonistycznego stały się podstawą teoretycznej koncepcji, którą stworzył w XX wieku J.M. Keynes. Po wielkim kryzysie lat 1929-1933 normatywne postulaty ekonomii zostały zasadniczo przewartościowane. Polityka budżetowa stać się miała centralnym instrumentem

\footnotetext{
10 M. Poniatowicz, op.cit., s. 45.

11 P.A. Samuelson, W.D. Nordhaus, Ekonomia I, Wydawnictwo Naukowe PWN, Warszawa 2000, s. 525.

12 M. Poniatowicz, op.cit., s. 46; D.N. Hyman, Public Finance, North Carolina State University, 2002, s. 573-581; D. King, Local Government Economics in Theory and Practice, Routledge, London 1992, s. $23-42$.

13 P.M. Gaudemet, J. Molinier, Finanse publiczne, PWE, Warszawa 2000, s. 166.

14 W. Ziółkowska, Finanse publiczne. Teoria i zastosowanie, Wydawnictwo Wyższej Szkoły Bankowej, Poznań 2005, s. 32.
} 
polityki antycyklicznej, a cnota równowagi budżetowej straciła swój urok ${ }^{15}$. Według jego poglądów gospodarka kapitalistyczna funkcjonuje w warunkach braku równowagi, niepełnego wykorzystania zdolności wytwórczych oraz bezrobocia. Głównym źródłem zakłóceń jest ograniczona zdolność podmiotów prywatnych do inwestowania. To ona tworzy pole dla interwencjonizmu państwowego. Uważał, że w tych warunkach państwo za pomocą dochodów i wydatków reguluje popyt gospodarczy. J.M. Keynes dopuszczał występowanie deficytów budżetowych w warunkach kryzysu. Uważał, że w warunkach kryzysu deficyt nie jest zjawiskiem negatywnym, wręcz odwrotnie - może pomóc wejść na drogę wzrostu gospodarczego ${ }^{16}$.

Koncepcje J.M. Keynesa rozwijał w XX wieku A.H. Hansen. Odrzucił pogląd konserwatystów, którzy twierdzili, że dług publiczny dla państwa jest zawsze szkodliwy. Uważał, że wszystko zależy od warunków i sytuacji, w jakich zaciągany jest dług. A ograniczenie wahań cyklu koniunkturalnego jest rzeczą nadrzędną ${ }^{17}$.

W latach 40. zaciąganie zobowiązań przestało być uważane za dowód słabości państwa, zaczęto je traktować jako źródło finansowania wydatków, którymi państwo równoważyło wielkość globalnego popytu z wielkością globalnej podaży, w szczególności wydatków inwestycyjnych wywierających mnożnikowy wpływ na produkcję. Zarządzanie długiem państwowym stało się podstawowym narzędziem niwelowania wahań cykli koniunkturalnych ${ }^{18}$. Z punktu widzenia gospodarki danego kraju istotne są cele, których finansowaniu służy emisja długu oraz jego poziom i struktura. Dług publiczny może działać prorozwojowo, ale po przekroczeniu określonego pułapu może ograniczać lub stanowić poważną przeszkodę dla dalszego stabilnego i zrównoważonego rozwoju kraju ${ }^{19}$. J. Tobin dostrzegał dwa zagrożenia związane z długiem publicznym. Pierwsze zagrożenie sprowadza się do efektu wypychania, gdyż zaciągając dług na finansowanie deficytu, wykorzystane są oszczędności, które mogłyby zostać użyte na inwestycje w kapitał produkcyjny i przez to podwyższyć płace realne, jakie zarabiałyby następne pokolenia. Drugie zagrożenie związane było z narastającymi kosztami obsługi długu publicznego, które powiększają deficyt budżetowy, a w konsekwencji prowadzą do zwiększenia długu publicznego. Przejawem obaw o skutki wzrastających kosztów obsługi jest tzw. koncepcja dopuszczalnego przyrostu długu J. Tobina. Koncepcja ta opiera się na zasadzie, że dług publiczny

15 S. Bugaj, Budżet i podatki, czyli spór o ustrój, „Przegląd Społeczny” nr 5, 6, 1998.

16 W. Ziółkowska, op.cit., s. 33.

17 Ibidem.

18 M. Bitner, E. Chojna-Duch, Dług publiczny i deficyt sektora finansów publicznych, w: Prawo finansowe, red. E. Chojna-Duch, H. Litwińczuk, Oficyna Prawa Polskiego, Warszawa 2007, s. 118.

19 B. Jajko, op.cit., s. 9. 
należy utrzymywać w stałej proporcji do produktu narodowego brutto ${ }^{20}$. Współczesne poglądy ekonomiczne łączą tradycyjną analizę keynesowską z elementami monetaryzmu, które są określane mianem neokeynesizmu. Brytyjski ekonomista W. Beveridge pod wpływem poglądów Keynesa rozwinął teorię systematycznego deficytu. Teoria ta opierała się na założeniu, że w pewnych sytuacjach deficyt budżetowy jest nie tylko potrzebny, ale wręcz pożądany, a związany z nim większy wolumen wydatków publicznych zwiększa krajowy popyt globalny i staje się istotnym bodźcem do pobudzania rozwoju gospodarczego. Ta koncepcja pomija możliwe, negatywne skutki związane ze zwiększeniem wydatków publicznych. Gospodarka z ciągłym deficytem jest w coraz większym stopniu obciążona kosztami rosnącego długu publicznego. W takiej sytuacji państwo traci kredyt zaufania, czego konsekwencją jest wzrost stóp procentowych. W pewnych sytuacjach państwo jest zmuszone do pokrywania deficytu ze źródeł nadzwyczajnych, np. w drodze dodatkowej emisji pieniądza. To zjawisko jest określane mianem monetaryzacji, a nieuchronną konsekwencją jest nasilanie procesów inflacyjnych ${ }^{21}$.

M. Poniatowicz wyróżnia również teorię deficytu cyklicznego i teorię impasu. Pierwsza z nich głosi, że deficyt budżetowy stanowi rezultat oddziaływania wahań koniunkturalnych w gospodarce, a niedobory budżetowe powstające w latach kryzysów można pokrywać nadwyżkami powstającymi w okresach prosperity. Zdaniem M. Poniatowicz w praktyce teoria deficytu cyklicznego może napotkać wiele trudności. Barierą może być brak możliwości dokładnego przewidzenia długości trwania cyklu koniunkturalnego oraz problem prawdopodobnej politycznej presji na zagospodarowanie nadwyżek budżetowych. Zatem nie ma gwarancji, że wysokość nadwyżek w okresie koniunktury pokryje późniejsze deficyty. O ile koncepcja deficytu cyklicznego nie podważa zasady równowagi budżetowej, o tyle koncepcja impasu to czyni. Deficyt budżetowy, w koncepcji impasu, określa nadwyżkę obciążeń definiowanych nad wpływami definiowanymi, nie uwzględnia różnic wynikających z operacji czasowych, np. pożyczek. Koncepcja ta pozwala na deficyt, ale z zachowaniem określonych warunków. W okresach ożywienia gospodarczego kreacja dodatkowego pieniądza, który pokrywałby zwiększone wydatki, jest kompensowana wzrostem produkcji. Można zatem uznać, że jest to dystrybucja dodatkowej siły nabywczej drogą operacji budżetowych bez inflacji i deprecjacji pieniądza, gdyż wzrost produkcji równoważy tę masę pieniądza. Według P.M. Gaudemet jest to bezpieczna i dozwolona wielkość impasu. Impas jest dozwolony tylko wtedy, gdy nadwyżka wydatków

20 A. Moździerz, Nierównowaga finansów publicznych, PWE, Warszawa 2009, s. 31; J. Tobin, Asset Accumulation and Economic Activity: Reflections on Contemporary Macroeconomics Theory, The University of Chicago Press, Oxford 1980, s. 49.

${ }^{21}$ M. Poniatowicz, op.cit., s. 50; M. Duverger, Finances publiques, Paris 1978, s. 256-272. 
publicznych służy finansowaniu wydatków produktywnych, przynajmniej do wysokości sumy nowych oszczędności, które może ściągnąć Skarb Państwa do opłacenia tych dodatkowych wydatków. Koncepcja ta też ma swoje wady. Nie ma bowiem żadnej pewności, że dodatkowa emisja pieniądza będzie skompensowana odpowiednim wzrostem podaży dóbr i usług. Ponadto trudno jest przewidzieć wysokość impasu w powiązaniu z przewidywanym stanem koniunktury gospodarczej ${ }^{22}$.

A.H. Hansen postulował opracowanie dwóch budżetów. Budżet operacyjny, który byłby związany z realizacją bieżących zadań publicznych, oraz budżet kapitałowy, który stanowiłby plan długoterminowych wydatków publicznych i byłby źródłem finansowania realizowanych przez państwo zadań inwestycyjnych. Bardziej skrajne stanowisko zarówno w sprawie zastosowania finansów publicznych, jak i instrumentu polityki gospodarczej państwa zajmuje amerykański ekonomista Abba Lerner - zwolennik teorii J.M. Keynesa, twórca finansów funkcjonalnych. Zaleca on stosowanie wszystkich instrumentów polityki finansowej państwa, które są skuteczne, tj. nie tylko podatków, ale także zaciąganie długu publicznego, a nawet emisję i wycofywanie pieniądza z obiegu. Popiera wzrost wydatków publicznych w momentach, kiedy wydatki prywatne nie zabezpieczają pełnego zatrudnienia ${ }^{23}$.

J.M. Buchanan, twórca teorii wyboru społecznego, dowodzi, że podstawowym kryterium dokonywania wydatków publicznych powinno być maksymalizowanie społecznej użyteczności lub ogólnego dobrobytu. Podstawowe założenie jego koncepcji jest następujące: dług publiczny jest korzystny, dopóki przynosi większy efekt dla społeczeństwa niż poniesione przez społeczeństwo zwiększone ciężary podatkowe spowodowane obsługą kosztów zadłużenia. Prezentowana teoria rodzi jednak wątpliwość, jak mierzyć społeczną użyteczność wydatków publicznych, zwłaszcza ze względu na jej subiektywny charakter ${ }^{24}$.

W latach 70. skuteczność interwencjonizmu państwowego została znacznie osłabiona. Gospodarka przodujących krajów zachodnich popadła w stagnację objawiającą się niską stopą wzrostu gospodarczego, wzrostem bezrobocia i wysoką inflacją. Tradycyjne metody interwencjonizmu nie przynosiły już rezultatów. Był to pierwszy z sygnałów, że ten sposób na rozwój gospodarczy nie jest dobrym rozwiązaniem. Państwo zostało oskarżone przez teoretyków finansów publicznych o wywoływanie inflacji i kreowanie deficytu budżetowego oraz powiększanie długu publicznego ${ }^{25}$.

22 P.M. Gaudemet, J. Molinier, op.cit., s. 51.

${ }^{23}$ M. Poniatowicz, op.cit., s. 52; A.B. Laffer, M.A. Miles, International Economics in a Integrated World, Glenview 1982.

${ }_{24}$ M. Poniatowicz, op.cit., s. 53; zob. J.M. Buchanan, Public Principles of Public Debt: A Defense and Restatement, 1958, Liberty Fund, Inc., Indianapolis 1999.

${ }_{25}$ M. Postuła, W tyglu naszych finansów. Transformacja i reformy finansów publicznych $w$ Polsce w dwudziestoleciu 1989-2008, Wydawnictwo WSPiZ, Warszawa 2007, s. 29. 
Nastąpił więc odwrót od keynesizmu, a popularność zaczęły odzyskiwać szkoły ekonomiczne wywodzące się z klasycznej teorii ekonomii. Monetaryści, których przedstawicielem był M. Friedman, uważali, że gospodarka ze swej natury ma charakter stabilny i powróci do swojego naturalnego stanu po każdym okresie przejściowej nierównowagi. Odrzucają wszelkie formy interwencjonizmu państwowego, z wyjątkiem polityki monetarnej, jako zakłócające naturalną grę sił rynkowych. Według monetarystów niezrównoważenie budżetu oraz powiększenie długu publicznego prowadzi w konsekwencji do inflacji, zwłaszcza w sytuacji, gdy deficyt budżetowy finansowany jest przez emisję dodatkowego pieniądza, a nie przez zaciąganie pożyczek na rynku kapitałowym ${ }^{26}$. Postulują maksymalną bierność państwa wobec zjawisk gospodarczych, zaś wszelką ingerencję uznają za szkodliwą. Przyczyną wahań w gospodarce jest, ich zdaniem, niedostateczna elastyczność cen. Zgodnie z tą teorią wraz z upływem czasu elastyczność cen rośnie i ceny w coraz bardziej doskonały sposób regulują procesy gospodarcze. Całokształt polityki gospodarczej powinien sprowadzać się jedynie do polityki monetarnej. Ta zaś powinna ograniczać się tylko do kontroli agregatów pieniężnych, bez aktywnego wykorzystywania stopy procentowej ${ }^{27}$.

Pod koniec lat 70. pojawił się nurt zwany ekonomią podażową. Jego zwolennicy poddawali krytyce zarówno poglądy keynesistów, jak i monetarystów, jako nieuwzględniające społecznego aspektu zjawisk gospodarczych. Zdaniem zwolenników teorii podażowej interwencjonizm powinien ograniczać się jedynie do zapewnienia gwarancji praw własności, bezpieczeństwa i ostrożnej polityki pieniężnej²8.

\section{Budżet Unii Europejskiej a perspektywa finansowa Unii Europejskiej}

Finansowanie działalności Unii Europejskiej należy do najczęściej dyskutowanych i wzbudzających wiele kontrowersji i problemów. System organów finansowych oraz metody finansowania struktur integracji europejskiej ulegały zmianom w toku ewolucji Wspólnot Europejskich. Obecny system finansowy Unii jest skomplikowany

26 M. Poniatowicz, op.cit., s. 54; R.A. Musgarve, P.B. Musgarve, Public Finance in the Theory and Practice, McGraw-Hill, New York 1984, s. 682; por. C.E. Dumas, The Effects of Government Deficits, Princeton University Press, Princeton 1985; G. Faerber, Local government borrowing in Germany, w: Local Public Finance in Europe, Balancing the Budget and Controlling Debt, red. B. Daffon, Northampton, MA, USA 2002, s. 142-143; A. Missale, Public Debt Management, Oxford University Press, Inc., New York 1999, s. 10-49.

27 W. Ziółkowska, op.cit., s. 36.

${ }_{28}$ M. Poniatowicz, op.cit., s. 55. 
ze względu na fakt, że struktury integracyjne stanowią kompleks organów, reguł, mechanizmów, których zadaniem jest nie tylko sfinansowanie działalności samych organizacji wspólnotowych, ale również różnorodnej polityki przewidzianej w traktatach $^{29}$. Istota dotychczasowego procesu integracyjnego w ramach Unii Europejskiej sprowadzała się do łączenia krajów w jeden wielki rynek wspólnotowy. Uczestniczące $\mathrm{w}$ tym procesie kraje przyjęly zasadę, że podstawową w nim rolę powinien odgrywać mechanizm rynkowy. W krajach o gospodarce rynkowej jednym z podstawowych instrumentów urzeczywistniania celów polityki gospodarczej jest budżet ${ }^{30}$. Działalność Unii Europejskiej jest finansowana obecnie z budżetu ogólnego oraz dwóch źródeł pozabudżetowych: Europejskiego Funduszu Rozwoju oraz operacji kredytowych i pożyczkowych na rynkach finansowych. Ponadto działalność UE jest wspomagana przez instytucje finansowe, tj. Europejski Bank Inwestycyjny, Europejski Fundusz Inwestycyjny oraz Europejski Bank Odbudowy i Rozwoju. Najważniejszą rolę odgrywa budżet ogólny, na który przypada ponad 95\% dochodów i wydatków UE ${ }^{31}$.

Budżet ogólny UE jest planem finansowym działalności wspólnot opracowywanym i wykonywanym przez Komisję Europejską i podległe jej podmioty. Plan ten obejmuje dochody i wydatki wspólnot przewidywane w okresie rocznym. Dochody i wydatki budżetowe są uchwalane przez Radę Unii Europejskiej i Parlament Europejski w formie aktu prawnego. Prawne znaczenie budżetu wyraża się w uprawnieniu Komisji Europejskiej do pobierania dochodów i dokonywania wydatków, natomiast nie upoważnia jej do nakładania ciężarów podatkowych na konkretnych podatników. Wszystkie czynności KE w zakresie wydatkowania środków budżetu UE odbywają się na podstawie odpowiednich aktów wykonawczych do budżetu ${ }^{32}$. Polityka społeczno-gospodarcza UE i tym samym funkcje budżetu UE zostały zdeterminowane dwiema zasadami: subsydiarności (pomocniczości) oraz zrównoważenia budżetu. Według pierwszej zasady działania publiczne powinny być wykonywane przez jak najniższy szczebel władzy publicznej. W przypadku, gdy nie przynoszą oczekiwanych rezultatów, kompetencje do ich wykonywania powinny posiadać władze szcze-

29 Treaty of 18 April 1951 establishing the European Coal and Steal Community, art. 2, 3 i 78; Treaty of 25 March 1957 establishing the European Economic Community, art. 199; Treaty of 25 March 1957 establishing European Atomic Energy Community, art. 174; Treaty of 8 April 1965 establishing a Single Council and a Single Commission of the European Communities, OJ L 152, 13/07/1967, art. 1, 9 i 20; Treaty of Nice amending the Treaty on European Union, the Treaties establishing the European Communities and cert in related acts: Protocols Annexed To The Treaty Establishing The European Community, Protocol on the financial consequences of the expiry of the ECSC Treaty and on the research fund for coal and steal, OJ C 080, 10/03/2001.

30 J. Soboń, Budżet Unii Europejskiej, Oficyna Wydawnicza ASPRA-JR, Warszawa 2008, s. 8.

${ }^{31}$ European Union, Public Finance, European Communities, Luxemburg 2002, s. 128.

32 M. Cieślukowski, Budżet Unii Europejskiej, Wydawnictwo Akademii Ekonomicznej w Poznaniu, Poznań 2006, s. 15-16. 
bla wyższego ${ }^{33}$. W odniesieniu do UE należy tę zasadę rozumieć w ten sposób, że UE działa jedynie w granicach określonych traktatami. Może podejmować działania zaradcze w innych obszarach, jeżeli czynności podejmowane przez państwo członkowskie nie przynoszą oczekiwanych rezultatów ${ }^{34}$.

System finansowania wydatków Unii Europejskiej od początku jej powstania uległ istotnej ewolucji. Było to efektem wielu reform wywołanych koniecznością złagodzenia kryzysu politycznego towarzyszącego negocjacjom budżetowym. W porównaniu z budżetami narodowymi wydatki UE mają zupełnie inny charakter. W budżecie UE nie ponosi się wydatków na edukację, zdrowie czy ochronę. Nie ponosi się wydatków na obsługę długu publicznego. Największa ich część jest przeznaczana na rolnictwo, a szczególne na działania interwencyjne na rynkach rolnych w celu zagwarantowania stabilności cen płodów rolnych i utrzymania ich na wyższym poziomie niż ceny światowe. Odmienność funkcjonowania budżetu UE jest związana z podziałem wydatków na obligatoryjne i nieobligatoryjne. Wydatki obowiązkowe są związane z funkcjonowaniem UE, umożliwiają wywiązywanie się z obowiązków wewnętrznych i zewnętrznych wynikających z traktatów lub z aktów prawnych uchwalonych na ich podstawie. Do tej grupy wydatków zalicza się wydatki na rolnictwo oraz wydatki zewnętrzne wynikające z umów z państwami trzecimi. Wydatki nieobowiązkowe obejmują fundusze strukturalne, wydatki administracyjne oraz wydatki związane z polityką wewnętrzną. Wydatki obowiązkowe są ustalane przez Radę UE i uchwalane przez Parlament UE, natomiast wydatki nieobowiązkowe są uchwalane ostatecznie przez Parlament, który ma prawo odrzucić propozycje Rady UE większością 3/5 głosów deputowanych obecnych podczas głosowania ${ }^{35}$.

Kluczową rolę przy tworzeniu budżetu Unii Europejskiej odgrywa perspektywa finansowa. Obejmuje ona siedem lat i stanowi ramy, w których powinny się mieścić corocznie uchwalane budżety. Jest ważną decyzją polityczną państw członkowskich dotyczącą finansowania UE. Wszystkie wydatki są w perspektywie finansowej podzielone na grupy będące odbiciem aktualnych priorytetów politycznych UE $\mathrm{w}$ danym okresie. W odniesieniu do każdej z grup określany jest maksymalny pułap wydatków oraz środki w kolejnych latach ${ }^{36}$. Perspektywa finansowa jest ogólnym planem dochodów i wydatków UE w średnim okresie. Podstawowy związek między perspektywą finansową a budżetem ogólnym wyraża się w tym, że wielkość dochodów

33 I. Begg, N. Grimwade, Paying for Europe, Sheffield Academic Press, Sheffield 1998, s. 104.

34 European Union, Consolidated versions of the Treaty on European Union and of the Treaty establishing the European Community, OJ C 325, 24/123/2002, art. 2.

35 J. Soboń, op.cit., s. 23-25.

36 E. Małuszyńska, B. Gruchman, Kompendium wiedzy o Unii Europejskiej, PWN, Warszawa 2005, s. $80-81$. 
i wydatków, określona w perspektywie w poszczególnych latach, stanowi jednocześnie górny limit dla uchwalanych corocznie dochodów i wydatków budżetowych ${ }^{37}$. Poczynione ustalenia przez kraje członkowskie, $w$ trakcie przyjmowania perspektywy finansowej, są zatwierdzane obowiązującym przez siedem lat aktem prawnym Unii Europejskiej, jakim jest Porozumienie międzyinstytucjonalne między Radą, Parlamentem i Komisją Europejską. W trakcie ustalania rocznych budżetów wszystkie instytucje biorące $\mathrm{w}$ tym udział są zobligowane do przestrzegania ustalonych w perspektywie finansowej pułapów wydatków. Istotne są dwa aspekty dotyczące perspektywy finansowej. Nie może być ona traktowana jako zwykłe programowanie finansowe, ponieważ założone w niej pułapy wydatków w poszczególnych grupach oraz ogólny pułap zasobów własnych mają w zasadzie charakter wiążący w procesie uchwalania budżetów rocznych. Drugim aspektem jest to, że w perspektywie finansowej określane są tylko główne grupy wydatków. W rocznym budżecie wydatki są określane bardziej szczegółowo. Istnieje zatem swoboda w określaniu wydatków w ramach poszczególnych grup. Konieczność dostosowania perspektywy finansowej do sytuacji istniejącej w danym roku wynika $\mathrm{z}$ następujących powodów:

- inflacji, która nie jest uwzględniana w momencie przygotowania perspektywy finansowej,

- potrzeby uwzględniania najnowszych danych dotyczących PNB w celu oszacowania pułapu dostępnych środków własnych,

- konieczności stosowania zasad indeksacji PNB przy kalkulacji niektórych wydatków związanych z rolnictwem ${ }^{38}$.

Do tej pory uchwalono cztery perspektywy finansowe na lata: 1988-1992, 1993-1999, 2000-2006 oraz 2007-2013.

Wydatkowanie środków z budżetu ogólnego UE, w tym z funduszy strukturalnych, Funduszu Spójności i innych, określają akty prawne stanowione przez organy UE. Na ich podstawie każde państwo członkowskie jest zobowiązane do stworzenia odpowiedniego systemu wdrażania tych środków, w tym systemu finansowania. Rozporządzenia te określają tryb przygotowania dokumentów planistycznych, na podstawie których każde państwo członkowskie może precyzować priorytety prowadzenia polityki społeczno-gospodarczej, zgodne z głównymi kierunkami rozwoju UE i polityką społeczno-gospodarczą UE. Zgodnie z rozporządzeniami Rady (WE) nr 1260/1999 ustanawiającym przepisy ogólne w sprawie funduszy strukturalnych ${ }^{39}$

37 M. Cieślukowski, Znaczenie perspektywy finansowej w systemie budżetowym Wspólnot Europejskich, w: Unia Europejska. Gospodarka Polski na drodze do Unii Europejskiej, „Zeszyty Naukowe WSB w Poznaniu" nr 15, 2002, s. 146-150.

38 E. Małuszyńska, B. Gruchman, op.cit., s. 80-81.

39 DzU UE L 99.161.1 z dnia 26 czerwca 1999 r. 
oraz nr 1083/2006 z dnia 11 lipca 2006 r. ustanawiającym przepisy ogólne dotyczące Europejskiego Funduszu Rozwoju Regionalnego, Europejskiego Funduszu Społecznego oraz Funduszu Spójności i uchylające rozporządzenie (WE) nr 1290/199940, rozporządzeniu Komisji (WE) nr 1828/2006 z dnia 8 grudnia 2006 r. ustanawiające szczegółowe zasady wykonania rozporządzenia Rady (WE) nr 1083/2006 oraz rozporządzenia (WE) 1080/2006 Parlamentu Europejskiego i Rady w sprawie Europejskiego Funduszu Rozwoju Regionalnego ${ }^{41} \mathrm{w}$ celu uruchamiania środków na realizację projektów finansowanych ze środków funduszy strukturalnych konieczne jest opracowanie krajowych strategicznych dokumentów programowych ${ }^{42}$. Dokumenty te są podstawą prowadzenia właściwej polityki rozwoju, a jej istotą jest hierarchizacja celów, która umożliwia klarowny obraz celów i kierunków rozwoju społeczno-gospodarczego, podporządkowanie działań doraźnych działaniom długofalowym, koordynację przemian gospodarczych i społecznych, maksymalne wykorzystanie silnych stron i szans rozwojowych, lepsze zagospodarowanie zasobów, większe szanse na uzyskanie dodatkowych zewnętrznych źródeł zasilania ${ }^{43}$.

\section{Finansowanie projektów ze środków funduszy strukturalnych UE w ramach perspektywy finansowej 2004-2006 a dług publiczny w Polsce}

W punkcie 1 przedstawiono przegląd teorii finansów publicznych, które stanową element ogólnej teorii ekonomicznej. Można stwierdzić za M. Poniatowicz, że występują dwie, sprzeczne ze sobą, doktryny dotyczące długu publicznego. Pierwsza z nich, „ortodoksyjna doktryna długu publicznego”, zakłada, że narastający deficyt budżetowy, a w konsekwencji powstający dług publiczny są przejawami wadliwie działającego systemu finansów publicznych. Jest to nie tylko sprzeczne z neutralną

${ }^{40}$ DzU UE L.06.210.25

${ }^{41}$ DzU UE L.06.371.1.

42 Więcej na temat strategii i planowania: R. Domański, Strukturalne zmiany systemów geograficznych spetniających warunki rozwoju podtrzymywanego, w: Strategie rozwoju wielkich miast, red. R. Domański, „Biuletyn PAN” z. 169, 1995, s. 8; J. Kołodziejski, A. Tyszecki, Modelowanie gospodarki przestrzennej ekologicznie uwarunkowanej, Wydawnictwo SGGW, Warszawa 1991, s. 126; A. Klasik, Strategie regionalne. Formułowanie i wprowadzanie w życie, Wydawnictwo Akademii Ekonomicznej w Katowicach, Katowice 2002, s. 29; A. Karpiński, Jak tworzyć długookresowa strategię dla kraju i regionu, Elipsa, Warszawa 2002, s. 17; W. Kłosowski, J. Warda, Wyspy szans. Jak budować strategie rozwoju lokalnego?, Warda \& Kłosowski Consulting, Bielsko-Biała 2001, s. 16; W. Breński, A. Oleksiuk, Strategiczne szanse polskiej gospodarki w kontekście globalizacji, Difin, Warszawa 2008, s. 86.

43 A. Potoczek, Współczesne formy rozwoju lokalnego i regionalnego, Wyższa Szkoła Humanistyczno-Ekonomiczna we Włocławku, Włocławek 2000, s. 79-80. 
rolą państwa, ale także szkodliwe dla tej gospodarki oraz nieetyczne. Druga ze skrajnych teorii zakłada, że państwo nie tylko może się zadłużać, ale wręcz powinno to czynić. Doktryna ta wskazuje na obowiązek interwencyjnej roli państwa w pobudzaniu wzrostu gospodarczego, a deficyt budżetowy i dług publiczny są w niej traktowane jako jedne z możliwych instrumentów tej interwencji.

W związku z członkostwem Polski w Unii Europejskiej od dnia 1 maja 2004 roku oraz możliwością realizowania przedsięwzięć ze środków pochodzących z budżetu Unii Europejskiej pojawiła się konieczność odpowiedniego prawnego uregulowania statusu środków pochodzących z budżetu UE w polskim systemie finansów publicznych. W zmienionej ustawie $\mathrm{z}$ dnia 26 listopada $1998 \mathrm{r}$. o finansach publicznych ${ }^{44}$ do środków publicznych włączone zostały środki pochodzące z budżetu Unii Europejskiej, w tym środki przeznaczone na realizację programów przedakcesyjnych, środki pochodzące z funduszy strukturalnych i Funduszu Spójności, środki Europejskiego Funduszu Orientacji i Gwarancji Rolnych „Sekcja Gwarancji”. Środki te, jako środki publiczne, mogły być przeznaczane na wydatki publiczne, rozchody budżetu państwa i budżetów jednostek samorządu terytorialnego. Rozchodami według ww. ustawy były m.in. pożyczki udzielane na finansowanie zadań realizowanych z udziałem środków pochodzących z budżetu Unii Europejskiej, tzn. środki udzielone na „prefinansowanie”, podlegające refundacji z Komisji Europejskiej. Wobec tego prefinansowanie zadań realizowanych $\mathrm{z}$ udziałem środków pochodzących $\mathrm{z}$ budżetu Unii Europejskiej, w tym środki pochodzące z funduszy strukturalnych, było źródłem potrzeb pożyczkowych budżetu państwa i było zaliczane do długu publicznego.

Według definicji zawartej w ww. ustawie o finansach publicznych państwowy dług publiczny stanowi nominalne zadłużenie jednostek sektora finansów publicznych po konsolidacji, tj. po wyeliminowaniu wzajemnych zobowiązań pomiędzy jednostkami tego sektora. Relacja tej wielkości do PKB stanowi jeden z podstawowych mierników oceny stanu finansów publicznych.

W latach 2004-2006 wzrost państwowego długu publicznego wynikał z przyrostu zadłużenia Skarbu Państwa i jednostek samorządu terytorialnego. Przyrost długu krajowego wynikał przede wszystkim z finansowania potrzeb pożyczkowych budżetu państwa, w tym deficytu budżetowego oraz środków przekazanych na reformę ubezpieczeń społecznych. Ponadto, według oceny Najwyższej Izby Kontroli, przyrost długu wynikał z konieczności finansowania salda prefinansowania i rozchodów z tytułu funduszy strukturalnych i WPR oraz zapewnienia środków przechodzących

${ }_{44}$ DzU 2003 nr 15 poz. 148 z późn. zm. Autorka rozpoczyna analizę prawnych uregulowań od ustawy o finansach publicznych z 1998 r., gdyż przepisy tej ustawy miały zastosowanie w pierwszym roku członkostwa Polski w Unii Europejskiej przy opracowaniu zasad finansowania Sektorowych Programów Operacyjnych. 
na następny rok budżetowy. Z pozostałych czynników największy wpływ na przyrost długu miała konwersja zobowiązań ZUS wobec OFE z tytułu nieprzekazanych składek, która spowodowała wzrost długu krajowego, oraz indeksacja obligacji 12-letnich o stałym oprocentowaniu i kapitalizacja obligacji nierynkowych ${ }^{45}$. Ww. wnioski zostały także zawarte w Informacji o wynikach kontroli zarzadzania długiem Skarbu Państwa i płynnościa budżetu państwa, w której to NIK wskazuje, że „wśród pozostałych potrzeb pożyczkowych największe znaczenie dla przyrostu długu miało prefinansowanie zadań finansowanych $\mathrm{z}$ funduszy strukturalnych Unii Europejskiej. W latach 2006-2008 pozyskanie środków na ten cel spowodowało łączny wzrost zadłużenia Skarbu Państwa o 7,7 mld zł"46, co stanowiło $86 \%$ potrzeb pożyczkowych budżetu państwa w stosunku do łącznej kwoty przeznaczonej na udzielone pożyczki.

W 2007 roku tempo przyrostu państwowego długu publicznego uległo spowolnieniu w stosunku do lat poprzednich, co było skutkiem niższych potrzeb pożyczkowych związanych z finansowaniem deficytu budżetu państwa oraz stosunkowo wysokiego nominalnego wzrostu $\mathrm{PKB}^{47}$. W roku 2008 nastąpił znaczny wzrost długu publicznego - aż o 13,3\% w stosunku do roku 2007. W związku z tym relacja państwowego długu publicznego do PKB uległa zwiększeniu z 44,9\% w 2007 roku do 47,0\% w 2008 roku. Najwyższa Izba Kontroli ostrzegała, że utrzymanie lub dalsze pogłębienie dysproporcji między wskaźnikami wzrostu długu i PKB grozi przekroczeniem, najpóźniej w 2010 roku, pierwszego progu ostrożnościowego, określonego w art. 79 ust. 1 pkt 1 ustawy o finansach publicznych ${ }^{48}$.

Prezentowane wielkości należy odnosić do wysokości progów ostrożnościowych i sanacyjnych określonych w ustawie o finansach publicznych. Zgodnie z ustawą w przypadku, gdy poziom zadłużenia zbliża się do 50-55\% wartości relacji długu publicznego do PKB, Rada Ministrów uchwala projekt ustawy budżetowej o relacji deficytu do dochodów budżetu państwa w wysokości nie wyższej niż w roku bieżącym. Zatem w przypadku przyjęcia takiego samego systemu prefinansowania dla realizacji programów operacyjnych nowej perspektywy finansowej (a należy zauważyć, że Polska w perspektywie finansowej na lata 2004-2006 mogła wykorzystać 11 mld euro środków publicznych pochodzących z budżetu UE, natomiast

45 Analiza wykonania budżetu państwa i założeń polityki pieniężnej w 2006 r., Najwyższa Izba Kontroli, Warszawa, czerwiec 2007, s. 132; por. Analiza wykonania budżetu państwa i założeń polityki pieniężnej w 2007 r., Najwyższa Izba Kontroli, Warszawa, czerwiec 2008.

46 Informacja o wynikach kontroli zarządzania długiem Skarbu Państwa i plynnościa budżetu państwa, Najwyższa Izba Kontroli, Departament Budżetu i Finansów, Warszawa, czerwiec 2009, s. 16.

47 Analiza... w 2007 r., op.cit., s. 140.

48 Analiza wykonania budżetu państwa i założeń polityki pieniężnej w 2008 r., Najwyższa Izba Kontroli, Warszawa, czerwiec 2009, s. 144 
w perspektywie finansowej na lata 2007-2013 - 59 mld euro) relacja długu publicznego do PKB mogłaby się jeszcze bardziej pogłębić, gdyż potrzeby pożyczkowe budżetu państwa byłyby znacznie wyższe, co mogłoby realnie wpływać na pogorszenie stanu finansów publicznych.

W latach 2006-2008, jeśli mimo zmiennych warunków rynkowych i nierównomiernego rozkładu potrzeb pożyczkowych zapewnione było utrzymanie płynności państwa, to w roku 2008 na finansowanie deficytu i innych potrzeb pożyczkowych zostały wykorzystane czasowo środki z zaliczek funduszy strukturalnych Unii Europejskiej w wysokości 4657,2 mln zł. Takie rozwiązanie można byłoby ocenić jako gospodarne, gdyż ograniczało ponoszenie kosztów z tytułu emisji skarbowych papierów wartościowych. Pozostawało jednak w sprzeczności z art. 98 ust. 2 ustawy z dnia 30 czerwca 2005 r. o finansach publicznych, który nie przewidywał takiego źródła finansowania potrzeb pożyczkowych oraz z art. 202 ust. 1 tej ustawy, nakazującym wykorzystywanie środków unijnych zgodnie $\mathrm{z}$ ich przeznaczeniem określonym w umowach międzynarodowych, przepisach odrębnych lub deklaracji dawcy. W dokumentach tych nie przewidziano takiego przeznaczenia środków unijnych ${ }^{49}$.

W ramach perspektywy finansowej 2004-2006 generowane były także na inne koszty, które miały wpływ na kształt długu publicznego. Są to: nadkontraktacja, zamknięcie programów (płatności 5\%) oraz różnice kursowe. Mechanizm nadkontraktacji został opracowany w celu wykorzystania całości alokacji środków przyznanych Polsce na lata 2004-2006. Na jego podstawie podpisywano dodatkowe umowy, przewyższające alokację, licząc na dodatnie różnice kursowe oraz oszczędności powstałe na projektach. Istniało jednak ryzyko wynikające z rozliczenia programów operacyjnych oraz różnic kursowych. Przyjęto, że w przypadku, gdy umowy w ramach nadkontraktacji będą wyższe od całości alokacji przyznanej z funduszy strukturalnych UE na dany program operacyjny, wówczas koszt realizacji projektów danego programu operacyjnego poniesie budżet państwa. Wprowadzenie takiego mechanizmu wynikało $\mathrm{z}$ tego, że umowy na realizację projektu były podpisywane w walucie krajowej, natomiast rozliczenia z Komisją Europejską były prowadzone w euro. Mogły zatem powstać oszczędności w euro i ze środków zaoszczędzonych mogły być realizowane dodatkowe projekty.

W początkowym etapie wdrażania funduszy strukturalnych środki z tytułu refundacji poniesionych wydatków były przekazywane do beneficjentów z przekazanej przez Komisję Europejską zaliczki. Zarówno zaliczka, jak i płatności okresowe były przekazywane przez Komisję Europejską na rachunek funduszowy, np. Europejskiego Funduszu Społecznego lub Europejskiego Funduszu Rozwoju Regionalnego, otwarty

49 Informacja..., op.cit., s. 8-9. 
w Ministerstwie Finansów. Następnie środki te były przekazywane odpowiednio na rachunek programowy, właściwy dla każdego programu operacyjnego. A dalej z rachunku tego środki były przekazywane do instytucji zarządzającej odpowiednim programem operacyjnym, z którego następował zwrot do beneficjenta środków w takiej wysokości, w jakiej poniósł on wydatki. Wszystkie rachunki były prowadzone w euro, $\mathrm{z}$ wyjątkiem rachunku beneficjenta.

W związku z programem naprawczym wprowadzonym przez Ministerstwo Rozwoju Regionalnego w 2005 roku następowały przyspieszone wypłaty środków beneficjentom. Wypłaty te następowały z rachunków instytucji zarządzającej programem operacyjnym, na których, na skutek wydłużonego terminu oczekiwania na akceptację wniosków płatniczych przez KE, brakowało środków na dokonanie płatności na rzecz beneficjentów. Wobec tego konieczne było wprowadzenie dodatkowego zasilenia tych rachunków ze środków budżetu państwa. Problem ten nasilił się wraz z zaangażowaniem rzeczowym i finansowym projektów, gdy kwoty certyfikowanych płatności doszły do poziomu 95\%, bowiem Komisja Europejska, zgodnie z systemem wdrażania funduszy strukturalnych i rozporządzeniami regulującymi ten system, wstrzymuje wypłatę pozostałych 5\% płatności do momentu zamknięcia projektu i otrzymania wniosku o płatność końcową. Strona polska musiała wygospodarować dodatkowe środki finansowe na zakończenie realizacji tych projektów. Środki zasilające rachunek programowy stanowiły potrzeby pożyczkowe budżetu państwa, wpływały zatem na wysokość długu publicznego.

Wypłata środków $\mathrm{z}$ konta programowego była dokonywana po akceptacji wniosku o płatność w walucie polskiej. Płatność ta była przeliczana według średniego kursu kupna waluty ogłaszanego przez Narodowy Bank Polski. Natomiast wniosek o płatność do Komisji Europejskiej, po weryfikacji przez instytucję płatniczą, był przygotowywany według kursu euro z przedostatniego dnia kwotowania środków w Europejskim Banku Centralnym (EBC) w miesiącu poprzedzającym miesiąc, dla którego dokonywano przeliczenia kwot zawartych we wniosku. Ewentualnie powstałe ujemne różnice kursowe, wynikające z przeliczenia wydatków według kursu NBP a EBC, były pokrywane $z$ budżetu państwa.

Podsumowując rozważania dotyczące oddziaływania systemu finansowania projektów w ramach perspektywy finansowej 2004-2006 na dług publiczny, autorka dochodzi do wniosku, że na poziom długu publicznego niewątpliwie miał wpływ wprowadzony i uregulowany ustawą o finansach publicznych, mechanizm prefinansowania.

Przyczynił się on do wzrostu zadłużenia publicznego o 7,7 mld zł i tym samym oddziaływał na relację długu publicznego do PKB. Dodatkowym obciążeniem budżetu państwa, nie wliczając wkładu krajowego, mogły być koszty nadkontrak- 
tacji, różnic kursowych i dodatkowych potrzeb pożyczkowych państwa związanych z zamknięciem pomocy. Nie jest możliwe szczegółowe wyliczenie, w jakiej wysokości zostały poniesione dodatkowe wydatki. Trudno także oszacować wydatki wynikające $\mathrm{z}$ nadkontraktacji, gdyż ich rozliczenie jest ściśle powiązane $\mathrm{z}$ wahaniem kursu walutowego. Z uwagi na skomplikowany system rozliczenia wprowadzonych mechanizmów pozyskanie odpowiednich danych ze sprawozdań finansowych budżetu państwa nie jest możliwe. Trudne do oszacowania jest także określenie poziomu wydatków niekwalifikowanych, ujętych w umowach o dofinansowanie, koniecznych do poniesienia w ramach danego projektu. W przypadku państwowych jednostek budżetowych oraz jednostek samorządu terytorialnego koszty te były ponoszone także przez budżet państwa.

\section{Dochody z tytułu refundacji wydatków podlegających zwrotowi z Komisji Europejskiej a deficyt budżetu państwa}

Od roku 2007, zgodnie ze znowelizowaną ustawą z dnia 30 czerwca 2005 r. o finansach publicznych, środki pochodzące z budżetu Unii Europejskiej, podlegające refundacji, włączone zostały do budżetu państwa. Były zaliczane do kategorii wydatków i dochodów budżetu państwa. Do kategorii wydatków zaliczono także wydatki związane z finansowaniem perspektywy finansowej 2004-2006, a do dochodów budżetu państwa - środki z funduszy strukturalnych uzyskiwane z Komisji Europejskiej. Środki te, wyodrębnione na oddzielnym rachunku bankowym, stanowiły dochód budżetu państwa po dokonaniu przewalutowania i przekazaniu ich na rachunek dochodów budżetu państwa.

Generalnie wykonanie lub niewykonanie wydatków i dochodów oddziałuje na wysokość deficytu budżetu państwa. W pierwszym roku funkcjonowania tego systemu przepływu finansowych, tj. w roku 2007, dochody budżetu państwa z tytułu refundacji wydatków podlegających zwrotowi z Komisji Europejskiej wyniosły 7534,1 mln zł, z czego w ramach środków uzyskanych z funduszy strukturalnych 1699,4 mln zł, co stanowiło jedynie 22,8\% w stosunku do planowanych dochodów z tego tytułu. Na niższe, niż przewidywano, wykonanie dochodów wpływało:

- zrealizowanie przez dysponentów tylko 41,1\% kwoty planowanych wydatków podlegających refundacji, 
- nieuwzględnienie na etapie planowania rozbieżności między terminem wykonania wydatków a datą wpływu środków z Unii Europejskiej na ich refundację ${ }^{50}$.

W roku 2007 wykonanie wyższych, niż planowano w ustawie budżetowej, dochodów wystąpiło w warunkach wyższego od przewidywanego wzrostu gospodarczego. Wysoki poziom dochodów z podatku dochodowego od osób prawnych i fizycznych był wynikiem dobrej koniunktury gospodarczej i wywiązywania się podatników z obowiązków podatkowych.

Niewykonanie dochodów z tytułu refundacji poniesionych wydatków z UE był wynikiem niskiego wykonania zaplanowanych na rok 2008 zadań w ramach Narodowych Strategicznych Ram Odniesienia. Przyjąć też należy, że w latach 2007 i 2008 na rachunek dochodów budżetu państwa wpływały środki z tytułu refundacji z KE w ramach perspektywy finansowej 2004-2006. Był to ten okres, w którym zamykano perspektywę finansową 2004-2006. Należy też pamiętać o wprowadzonych dla tej perspektywy finansowej mechanizmach, mających na celu poprawę płynności dokonywanych płatności na rzecz beneficjenta, oraz to, że brak odpowiednich regulacji wpływał na dowolność podejmowanych decyzji przez Ministra Finansów o przekazywaniu środków otrzymanych z Komisji Europejskiej na wydzielony rachunek dochodów budżetu państwa, co również ujęła Najwyższa Izba Kontroli we wnioskach pokontrolnych w Analizie wykonania budżetu państwa i założeń polityki pieniężnej ${ }^{51}$.

W odpowiedzi na wnioski pokontrolne NIK dopiero w roku 2009 Minister Finansów określił, w wewnętrznych regulacjach, procedury przekazywania środków pochodzących z Unii Europejskiej z rachunków prowadzonych w euro na rachunek dochodów budżetu państwa. Środki te były przekazywane na podstawie harmonogramów wydatków przedstawianych przez dysponentów części budżetowych, a także rozliczenia wydatków w okresach półrocznych. Należy zwrócić uwagę na pewną niekonsekwencję tej procedury. Harmonogram wydatków jest jedynie ich planem, co niekoniecznie może oznaczać równowartość ponoszonych wydatków w ramach danego programu w danym okresie, gdyż realizacja projektów może się wydłużyć w czasie lub generować oszczędności.

Niski poziom wykonania wydatków na finansowanie projektów z udziałem środków Unii Europejskiej w latach 2007-2008 mógł być wynikiem przyjęcia zbyt optymistycznych założeń co do możliwości wdrożenia poszczególnych programów operacyjnych na etapie planowania budżetu państwa w roku 2007 i 2008 oraz nieskutecznej realizacji zadań w zakresie zarządzania i koordynacji przez odpowiednie instytucje. Ponadto przyczyną wpływającą na niewykonanie wydatków mógł być brak

\footnotetext{
50 Analiza... w 2007 r., op.cit., s. 62.

51 Analiza... w 2007 r., op.cit., s. 51; Analiza... w 2008 r., op.cit., s. 56.
} 
jednoznacznej interpretacji dotyczącej sposobu klasyfikowania i przekazywania środków na przygotowanie projektów planowanych do realizacji, zwłaszcza przed podpisaniem umowy o dofinansowanie. Rozporządzenie Ministra Rozwoju Regionalnego z dnia 7 września 2007 r. w sprawie wydatków związanych z realizacją programów operacyjnych ${ }^{52}$ uwzględniało taką możliwość, natomiast problem ich uruchomienia leżał po stronie Ministra Finansów, bowiem uruchomienie środków na finansowanie projektu, na który nie została podpisana umowa o dofinansowanie, skutkowałoby niezrealizowaniem dochodów z tytułu środków podlegających refundacji z KE, ponieważ nie podlegałyby one certyfikacji. To oznaczałoby poniesienie przez budżet państwa dodatkowych kosztów związanych z wdrażaniem funduszy strukturalnych.

Przyjęcie systemu finansowania programów operacyjnych realizowanych w ramach perspektywy finansowej 2007-2013, polegającego na włączeniu przepływów finansowych do budżetu państwa, mogło mieć na celu polepszenie wskaźnika zadłużenia publicznego. Przyjęcie tego systemu nastąpiło w okresie dobrej koniunktury gospodarczej, wysokiego wpływu dochodów do budżetu państwa z tytułu podatków pośrednich oraz dochodowych. Takie postępowanie może być przykładem presji politycznej na zagospodarowanie nadwyżek budżetowych oraz traktowania problemu zapewnienia finansowania programów operacyjnych jako tymczasowy i nieistotny, gdyż planowano w latach następnych zwiększone wpływy do budżetu państwa z ww. tytułu. W ten sposób następowałoby bilansowanie wydatków z dochodami. Nie przewidziano jednak ani długości trwania fazy wzrostu gospodarczego w cyklu gospodarczym, ani faktycznego napływu środków z Komisji Europejskiej, gdyż zależy on od prawidłowości funkcjonowania całego systemu wdrażania funduszy strukturalnych w Polsce, tzn. od funkcjonowania każdej instytucji biorącej udział w tym systemie. Innym problemem było też planowanie zarówno wydatków, jak i dochodów z tytułu refundacji z KE poniesionych wydatków. Powstaje pytanie, czy w ogóle w przypadku realizacji programów operacyjnych można prawidłowo je zaplanować.

W roku 2008 zaplanowano środki pochodzące z funduszy strukturalnych na finansowanie podlegające refundacji z UE w wysokości przewyższającej prawie czterokrotnie poziom tych wydatków z roku 2007. O ile w 2008 roku zaplanowano najwięcej środków na ten cel, o tyle wykonanie ich przez dysponentów części budżetowych było najniższe w porównaniu z latami 2007 oraz 2009 i wynosiło około 27\% (rysunki 1 i 2). Jedynie w roku 2009 wykonanie wydatków zarówno w ramach współfinansowania krajowego, jak i wydatków podlegających refundacji z UE wynosiło

${ }^{52} \mathrm{DzU} 2007 \mathrm{nr} 175$ poz. 1232 oraz zmiana tego rozporządzenia z dnia 10 lutego 2009 r., DzU 2009 nr 23 poz. 140. 
ponad 90\%. Wynikało to jedynie z uaktualnienia wydatków ujętych w znowelizowanej ustawie budżetowej na rok 2009.

Jeżeli zatem nie realizowano wydatków podlegających refundacji na takim poziomie, na jakim zostały zaplanowane (a należy pamiętać, że na zbliżonym poziomie planowano w danym roku budżetowym uzyskanie dochodów $\mathrm{z}$ tego tytułu), nie zrealizowano też dochodów z tytułu refundacji. Jeżeli zatem planowanie wydatków i dochodów z ww. tytułu oddziałuje na wysokość deficytu budżetu państwa, nierealne ich planowanie daje zafałszowany obraz stanu finansów publicznych. Przykładem może być rok 2009, w którym pierwotnie w ustawie budżetowej planowano dochody na poziomie 20631937 tys. zł, a wydatki na poziomie 28778259 tys. zł, natomiast po nowelizacji ustawy, w wyniku kryzysu gospodarczego, dochody określono na poziomie 27087780 tys. zł, a wydatki na poziomie 21790987 tys. zł. Po porównaniu tych danych można się zastanawiać, czy zmniejszenie deficytu budżetowego zostało dokonane przez planowane zwiększone dochody z tytułu refundacji środków z Komisji Europejskiej. Jak wykazano, w praktyce nie jest to źródło gwarantujące realizację planu dochodów.

\section{Rysunek 1. Wykonanie wydatków podlegających refundacji z UE w latach 2007-2010 ( $w$ mln euro)}

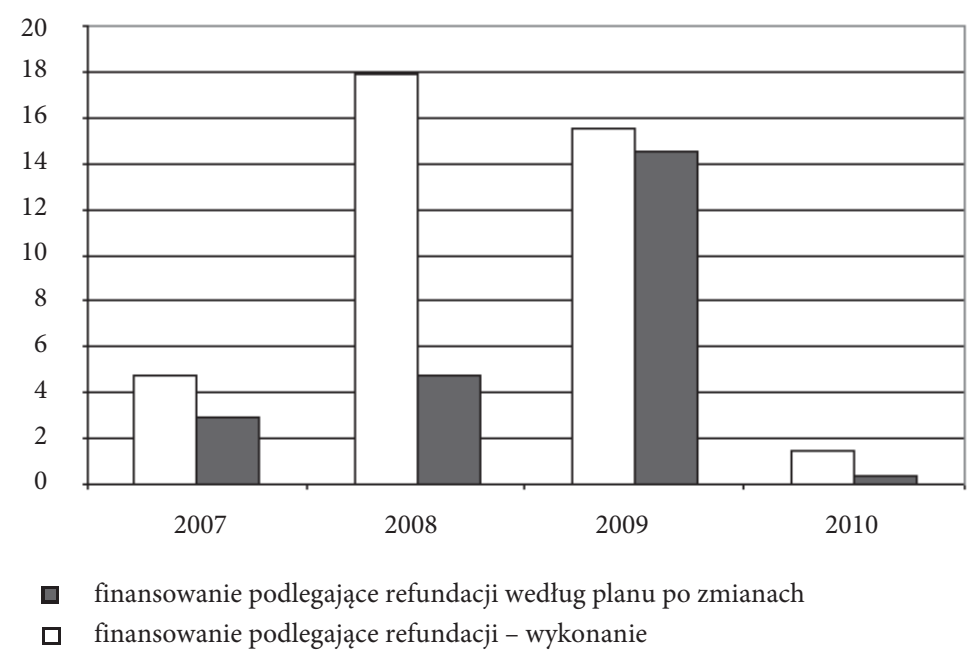

Źródło: Opracowanie własne na podstawie ustaw budżetowych na lata 2004-2010 oraz sprawozdań z wykonania budżetu państwa oraz ze sprawozdań miesięcznych z wykonania budżetu państwa w roku 2010. 


\section{Rysunek 2. Wykonanie wydatków wkładu krajowego w latach 2007-2010 ( $w$ mln euro)}

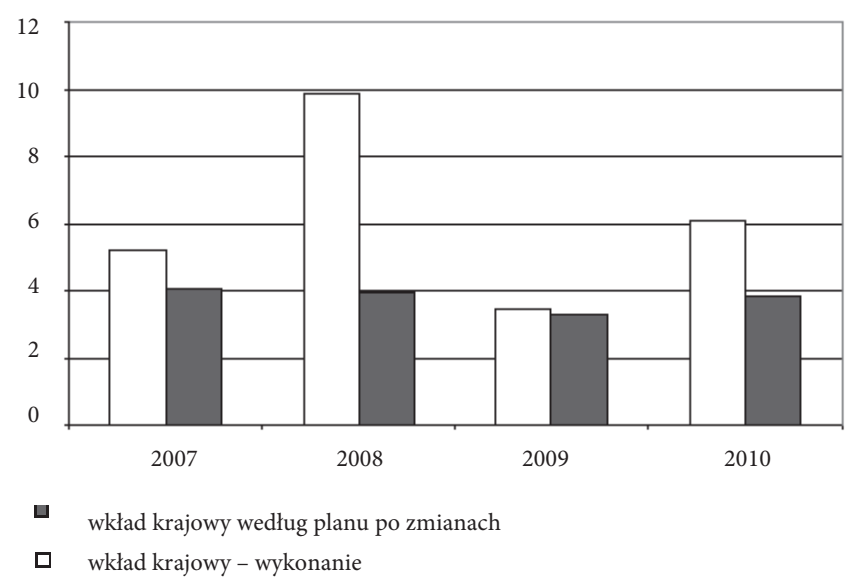

Źródło: Opracowanie własne na podstawie ustaw budżetowych na lata 2004-2010 oraz sprawozdań z wykonania budżetu 2004-2010.

W 2009 roku realizowanie planowanych dochodów z tytułu wydatkowania środków podlegających refundacji wynikało z sekwencyjnego przekazywania środków na rachunek dochodów budżetu państwa na podstawie harmonogramu wydatków przedkładanych przez dysponentów części budżetowych. Wysokość zrealizowanych dochodów w 2009 roku, podobnie jak w roku 2008, wynikała głównie z przekazywania środków pochodzących m.in. z zaliczki przyznanej Polsce przez KE. Z zaliczki tej były także przekazywane środki na inne cele niż tylko dochody budżetu państwa, m.in. na finansowanie potrzeb pożyczkowych budżetu państwa. W 2009 roku na ten cel przekazano $1200,0 \mathrm{mln}$ euro ${ }^{53}$. To mogło oznaczać poszukiwanie dodatkowego źródła, z którego bez dodatkowych kosztów można byłoby finansować dług publiczny.

System przepływów finansowych środków pochodzących z budżetu UE, w tym funduszy strukturalnych, polegający na włączeniu ich do budżetu państwa funkcjonował tylko trzy lata. W wyniku spowolnienia gospodarczego, niekorzystnej z fiskalnego punktu widzenia struktury tego wzrostu oraz wpływu reform strukturalnych na obniżenie poziomu dochodów sektora instytucji rządowych i samorządowych (m.in. obniżenie składki rentowej w latach poprzednich, obniżenie skali podatkowej w PIT od 2009 roku oraz korzystne dla podatników zmiany w rozliczaniu podatku VAT), a także wzrostu wydatków na realizację perspektywy finansowej 2007-2013 oraz

53 Analiza... w 2009 r., op.cit., s. 165. 
braku przewidywalności w realizacji dochodów z tytułu zwrotu środków z KE nastąpiło pogorszenie nierównowagi fiskalnej. W rezultacie deficyt wzrósł z 3,7\% PKB w 2008 roku do 7,1\% w 2009 roku. W świetle pogarszającej się sytuacji gospodarczej Polski utrzymanie ww. systemu w następnych latach skutkowałoby wzrostem wydatków na finansowanie perspektywy finansowej 2007-2013 i dalszym pogłębianiem deficytu budżetu państwa.

Przyczyny aktualnej sytuacji finansów publicznych należy upatrywać nie tyle w kryzysie gospodarczym, ile w nierównowadze fiskalnej o podłożu strukturalnym. Aktualny stan finansów publicznych w Polsce wynika z zaniechania wprowadzania zmian w tej sferze w okresie dobrej koniunktury gospodarczej w latach 2006-2007. W okresie tym zdecydowano się na wprowadzenie środków pochodzących m.in. z funduszy strukturalnych UE do budżetu państwa, chcąc poprawić stan zadłużenia publicznego, którego poziom zbliżał się do pierwszego progu ostrożnościowego, określonego ustawowo, lecz z drugiej strony pogorszono relację deficytu budżetu państwa do PKB. Była to decyzja dość odważna, ponieważ Polska nie jest krajem, w którym stan finansów publicznych jest na tyle stabilny, aby mógł udźwignąć ciężar takich rozwiązań systemowych.

Inne kraje członkowskie, mimo wyższego poziomu rozwoju gospodarczego, nie zdecydowały się na podobne rozwiązania lub z niego zrezygnowały, np. Niemcy oraz Francja. W obu krajach istnieje pozabudżetowe ujmowanie systemu finansowania programów operacyjnych, tj. nie finansuje się wydatków podlegających refundacji ze środków budżetowych państwa. Wydatki oraz dochody z tytułu refundacji przedkłada się jako informację dodatkową do ustawy budżetowej lub sprawozdania z wykonania budżetu państwa. W obu państwach położono nacisk na rozwiązania systemowe wdrażania funduszy strukturalnych, polegające na zobowiązaniu beneficjentów do regularnego składania wniosków płatniczych do KE.

Konsekwencją pogarszającego się stanu finansów publicznych, tj. wzrostu długu publicznego, który w 2010 roku prawdopodobnie osiągnie ustawowy próg 50\%, oraz wzrostu poziomu deficytu budżetu państwa było podjęcie przez Radę ECOFIN w dniu 7 lipca 2009 roku decyzji ${ }^{54}$ o istnieniu w Polsce nadmiernego deficytu i równocześnie wydanie zaleceń wynikających z Traktatu o funkcjonowaniu Unii Europejskiej dotyczących redukcji nadmiernego deficytu. Zgodnie z tymi zaleceniami Polska jest zobowiązania do roku 2012 zredukować nadmierny deficyt w sposób trwały i wiarygodny. Oznacza to wprowadzenie ograniczenia wzrostu wydatków publicznych przez wprowadzenie tzw. reguły wydatkowej. Reguła ta może być nałożona na całą stronę wydatkową lub na specyficzne typy wydatków. Planuje się, że będzie

\footnotetext{
${ }_{54} \mathrm{Na}$ mocy art. 126 ust. 7 Traktatu o Unii Europejskiej.
} 
ona ograniczać wzrost wydatków o charakterze uznaniowym, tj. elastycznych oraz nowych wydatków prawnie zdeterminowanych, tzw. sztywnych. Reguła ta będzie miała zastosowanie do dnia uchylenia ww. procedury. W następnym etapie zostanie wprowadzona reguła stabilizująca, która zapewni utrzymanie deficytu na niskim poziomie. Nie planuje się jednak stosowania tej reguły w odniesieniu do wydatków przeznaczonych na realizację programów operacyjnych perspektywy finansowej 2007-2013, finansowanych z funduszy strukturalnych UE.

\section{Finansowanie programów operacyjnych od 2010 roku - wzrost długu publicznego?}

Aby zapobiec pogłębianiu się deficytu budżetu państwa, m.in. z powodu ujęcia środków pochodzących $\mathrm{z}$ funduszy strukturalnych UE w budżecie państwa, ustawą z dnia 27 sierpnia 2009 r. o finansach publicznych wprowadzono nowe rozwiązania polegające na delegowaniu funkcji płatnika do Banku Gospodarstwa Krajowego, który w pierwszym okresie programowania 2004-2006 pełnił funkcję pożyczkodawcy dla beneficjentów, realizujących projekty finansowane ze środków funduszy strukturalnych. Z budżetu państwa wydzielono budżet środków europejskich. Można zadać sobie pytanie, czy wydzielony budżet środków europejskich wchodzi w skład budżetu państwa, czy też nie i z jakich środków będzie finansowany. Interpretacje są różne. Zgodnie z ustawą z dnia 27 sierpnia 2009 r. deficyt budżetu środków europejskich nie jest wliczany do ogólnego deficytu budżetu państwa, co powinno wpłynąć na poprawę tego miernika. Część środków przeznaczonych na wydatki ujęte w budżecie środków europejskich będzie pochodziła ze zwrotu środków z Komisji Europejskiej. Biorąc pod uwagę metodologię planowania dochodów z tytułu refundacji poniesionych wydatków, nadal wątpliwe jest uzyskanie corocznie środków na planowanym poziomie. Będzie zatem istniała konieczność wygospodarowania z budżetu państwa środków w wyższej wysokości na realizację programów operacyjnych ujętych $\mathrm{w}$ budżecie środków europejskich. Znowelizowana ustawa z dnia 27 sierpnia 2009 r. o finansach publicznych wprowadziła rozszerzenie pojęcia potrzeb pożyczkowych o nowy rodzaj deficytu, jakim jest deficyt środków europejskich. Należy przyjąć, że część środków przeznaczonych na ww. wydatki będzie pochodziła z emisji papierów

dłużnych, co będzie wpływało na poziom długu publicznego. Wprowadzenie od roku 2010 płatnika, jakim jest Bank Gospodarstwa Krajowego, jest i nie jest rozwiązaniem nowym. Autorka przypomina, że w tzw. starej perspektywie finansowej 2004-2006 BGK udzielał pożyczek, w formie tzw. prefinansowania, ze środków przekazanych 
z Ministerstwa Finansów. Obecnie Ministerstwo Finansów przekazuje środki do BGK, a ten w formie płatności do beneficjentów. Analizując podobieństwo mechanizmów prefinansowania oraz płatności przekazywanych beneficjentom z BGK, należy pamiętać o tym, że jeżeli potrzeby pożyczkowe państwa w mechanizmie prefinansowania spowodowały wzrost zadłużenia o $7,7 \mathrm{mld}$ zł, to wzrost potrzeb pożyczkowych związanych z zabezpieczeniem środków na płatności również może spowodować wzrost zadłużenia publicznego i pogorszenie wskaźnika długu publicznego w stosunku do PKB. Przy czym wzrost zadłużenia publicznego może w praktyce okazać się wyższy ze względu na przyznaną wysokość środków publicznych pochodzących m.in. z funduszy strukturalnych UE na realizację NSRO 2007-2013. Należy też pamiętać o tym, że już trwają prace w strukturach Unii Europejskiej nad kolejną perspektywą finansową 2014-2020. Planuje się, że Polska może otrzymać 80 mld euro pomocy publicznej. W roku 2014 ponownie nastąpi konieczność zapewnienia finansowania programów nowej perspektywy finansowej oraz zbliżające się ku końcowi finansowanie perspektywy finansowej 2007-2013.

Nadal zauważa się tendencję wzrostową długu publicznego. O ile w roku 2008 wyniósł on $47 \%$ w stosunku do $\mathrm{PKB}$, o tyle rok później wzrósł niebezpiecznie do poziomu $49,8 \%{ }^{55}$, po czym w roku 2010 osiągnął poziom 52,8\% - według wyliczeń Ministerstwa Finansów, tj. według metodologii krajowej. Natomiast według wyliczeń metodą unijną dług publiczny stanowił 54,9\% PKB. Należy przypomnieć, że osiągnięcie poziomu wskaźnika powyżej 55\% oznacza przekroczenie drugiego progu określonego w ustawie o finansach publicznych. Według ww. ustawy jeżeli wartość relacji kwoty państwowego długu publicznego do PKB jest większa niż 55\%, a mniejsza od 60\%, to na kolejny rok Rada Ministrów uchwala projekt ustawy budżetowej, w którym nie przewiduje się deficytu budżetu państwa lub przyjmuje się poziom różnicy dochodów i wydatków budżetu państwa, zapewniający, że relacja długu Skarbu Państwa do PKB przewidywana na koniec roku budżetowego, którego dotyczy projekt ustawy, będzie odpowiednio niższa. Nie przewiduje się wzrostu wynagrodzeń pracowników państwowej sfery budżetowej. Waloryzacja rent i emerytur nie może przekroczyć poziomu odpowiadającemu wzrostowi cen towarów i usług konsumpcyjnych, ogłoszonego przez GUS za poprzedni rok budżetowy. Ponadto wprowadza się zakaz udzielania pożyczek i kredytów z budżetu państwa, z wyjątkiem rat udzielnych w latach poprzednich. Nie przewiduje się także wzrostu wydatków. Rozpiętość w wyliczeniu wysokości długu publicznego według tych dwóch metodologii jest znacząca. Zdaniem autorki metodologia unijna wyliczania długu publicznego jest

${ }_{55}$ Poziom długu publicznego niebezpiecznie zbliżył się do pierwszego progu, dla którego określona granica w ustawie o finansach publicznych to $50 \%$. 
bardziej rzetelna niż metodologia krajowa. Dług sektora general goverment obliczany jest na potrzeby oceny spełnienia przez kraj członkowski UE kryterium konwergencji. Według zasady UE do wyliczenia poziomu długu włączono m.in. fundusze utworzone w ramach BGK, tj. Krajowy Fundusz Drogowy oraz Krajowy Fundusz Kolejowy $^{56}, \mathrm{z}$ których następuje finansowanie dużych projektów infrastrukturalnych m.in. w ramach Programu Operacyjnego Infrastruktura i Środowisko. Według NIK utrzymanie stanu zadłużenia w 2009 roku poniżej 50\% PKB było możliwe wskutek finansowania potrzeb pożyczkowych budżetu państwa środkami z zaliczek z Unii Europejskiej oraz przeniesienia finansowania części inwestycji drogowych $\mathrm{z}$ budżetu państwa do Krajowego Funduszu Drogowego. W interpretacji Ministerstwa Finansów wykorzystane środki z zaliczek Unii Europejskiej, mimo że muszą być zwrócone na odpowiedni rachunek w celu wykorzystania zgodnie z przeznaczeniem, nie są traktowane jako dług Skarbu Państwa. Formalnie po przekazaniu ich $\mathrm{w}$ formie zaliczki stały się one własnością Skarbu Państwa i w momencie wykorzystania na finansowanie potrzeb pożyczkowych budżetu państwa nie powstało zobowiązanie wobec innego podmiotu, które należałoby ująć w ewidencji długu. Gdyby zamiast środków, które na koniec 2009 roku pozostawały do zwrotu, analogiczna kwota została pozyskana na rynku skarbowych papierów wartościowych, poziom długu publicznego do PKB na koniec 2009 roku wyniósłby 50,1\% ${ }^{57}$.

Analizując poziom realizowanych dochodów i wydatków, należy zwrócić uwagę na różnicę, tj. deficyt w budżecie środków europejskich, który stanowi, zgodnie z ustawą o finansach publicznych, potrzeby pożyczkowe budżetu państwa. Jeśli w latach 2006-2008 potrzeby pożyczkowe państwa związane z prefinansowaniem wyniosły 7,7 mld zł, to tylko w roku 2009 wyniosły 4,4 mld zł, a w roku 2010 -10 mld zt ${ }^{58}$.

Warto się zastanowić, czy obecny system finansowania okaże się wystarczający dla zapewnienia ciągłości przepływu środków i jednocześnie nie będzie wpływał na obciążenie finansów publicznych.

\footnotetext{
56 Analiza... w 2010 r., op.cit., s. 193-196.

57 Analiza... w 2009 r., op.cit., s. 153.

58 Analiza... w 2010 r., op.cit., s. 178; Analiza... w 2009 r., op.cit., s. 123.
} 


\section{Wnioski}

$\mathrm{W}$ teorii długu publicznego jedną z koncepcji rozwiązywania problemów deficytu budżetu państwa jest nałożenie konstytucyjnych ograniczeń uniemożliwiających niekontrolowane zaciąganie długu publicznego. Polska jest krajem o niestabilnym systemie prawnym finansów publicznych, dostosowywanym w krótkich okresach do danej sytuacji gospodarczej i uzależnionym od programu gospodarczego elity politycznej sprawującej władzę. Stan finansów publicznych nie jest zadowalający, a częste zmiany tego systemu mają na celu wykazanie poprawy głównych mierników, tj. wysokości długu publicznego oraz deficytu budżetowego. Dokonywanie zmian w sposób kreatywny prowadzi do zafałszowania prawdziwego stanu finansów publicznych. W świetle aspiracji Polski do wstąpienia do strefy euro mogą istnieć obawy, czy w przyszłości Polska podzieli los Grecji, czy innych krajów, które weszły do strefy euro, a obecnie przeżywają kryzys finansów publicznych. Brak stabilnego systemu finansów publicznych, w tym stabilnego systemu finansowania inwestycji realizowanych ze środków pochodzących z funduszy strukturalnych UE, powoduje, że jest on mało przejrzysty i skomplikowany, chociażby ze względu na częste zmiany interpretacji przepisów. Obecne rozwiązania w zakresie ujęcia środków pochodzących z funduszy strukturalnych Unii Europejskiej w polskim systemie finansów publicznych znacznie obciążają budżet państwa, ale $\mathrm{z}$ drugiej strony czy nie należy przyjąć takiej sytuacji za normalną, która nie ulegnie zmianie? Czy tylko Polska zmaga się z tego typu problemem, czy inne kraje członkowskie także? W Polsce ustalono konstytucyjnie górny próg zadłużenia publicznego, który wynosi 60\%. Deficyt nie powinien kształtować się na wyższym poziomie niż 3\% w stosunku do PKB. Z dokonanych rozważań i analiz finansowych nasuwają się następujące wnioski: wprowadzone regulacje dotyczące ujęcia finansowania programów operacyjnych w systemie finansów publicznych mają niekorzystny wpływ zarówno na poziom długu publicznego, jak i deficytu budżetu państwa. Jednym z czynników wpływających na sprawność realizacji programów ujętych w perspektywach finansowych jest zapewnienie sprawnego przepływu środków przeznaczonych na ten cel. Przez wprowadzenie w Polsce rozwiązań tak znacznie obciążających budżet państwa mogą się one stać po części przyczyną trudności związanych z realizacją tych programów. W planowaniu wydatków i dochodów należy bowiem brać pod uwagę rzeczywiste możliwości budżetu państwa, tj. na ile można wygenerować wydatki na realizację programów operacyjnych oraz realne dochody z tego tytułu. Ale trzeba też pamiętać, że poziom planowanych w budżecie wydatków jest powiązany z wykorzystaniem alokacji funduszy strukturalnych zgodnie z zasadą $n+3$ i $n+2$. Istnieje 
zatem ograniczony horyzont czasowy, w którym Polska jako kraj członkowski może wydatkować środki pochodzące z budżetu UE bez konieczności ich zwrotu do KE. W przypadku potrzeby zwiększonych wydatków na realizację programów operacyjnych brak konstytucyjnie ustalonych progów zadłużenia prowadziłby do dalszego pogorszenia stanu finansów publicznych.

Rozważając problem finansowania programów operacyjnych i jego implikacji dla stanu finansów publicznych, należy także zastanowić nad efektywnością inwestycji realizowanych z funduszy strukturalnych. Wzrost zadłużenia sektora publicznego można byłoby uznać za tymczasowy w przypadku generowania w przyszłości dochodów ze zrealizowanych inwestycji, które będą miały wpływ na wzrost PKB. W tych rozważaniach nie można jednak zapominać o tym, że realizacja programów operacyjnych obejmuje nie tylko wydatki inwestycyjne, ale i bieżące, nie tylko wydatki kwalifikowalne, które będą zrefundowane z KE, ale też kwalifikowalne niepodlegające refundacji oraz niekwalifikowalne, niezbędne do poniesienia przy realizacji projektów. Nie można jednoznacznie stwierdzić, że dziś zaciągnięty dług będzie w przyszłości wyrównany refundacjami pochodzącymi z KE. Pojawia się także dodatkowy koszt w postaci oprocentowania długu. Fundusze strukturalne mają rozwijać gospodarkę, przyspieszać procesy rozwojowe kraju zacofanego gospodarczo, ale koszty generowane przy ich wdrażaniu, system przepływów finansowych mogą działać destabilizująco na sytuację finansów publicznych. Wprowadzenie opisanych rozwiązań do systemu finansów publicznych może stać się czynnikiem hamującym wydatkowanie tych środków ze względu na pewne ograniczenia, tj. ze względu na przyjęte wskaźniki określające poziom zaciągania długu publicznego oraz deficytu budżetu państwa. Planowane corocznie zwiększenie wydatków na realizację programów operacyjnych oznacza coroczne zwiększenie potrzeb pożyczkowych budżetu państwa, co może prowadzić do powstania pewnej spirali zadłużenia. Innymi konsekwencjami utrzymującego się stanu wysokiego długu publicznego i deficytu budżetu państwa, wymienianymi w literaturze przedmiotu, mogą być: wystąpienie tzw. 
negatywnego wpływu na saldo obrotów bieżących, występowanie efektu wypychania oraz przyspieszenie procesów inflacyjnych ${ }^{59}$. Jednakże nie są to obszary badane przez autorkę.

W literaturze przedmiotu środki pochodzące $\mathrm{z}$ funduszy strukturalnych zalicza się do instrumentów o charakterze interwencyjnym ${ }^{60}$. Instrumenty interwencyjne, które stosuje się najczęściej w gospodarkach zamkniętych i destabilizowanych, prowadzą do negatywnych skutków dla przemian gospodarczych, uzależniając je od zasilania zewnętrznego, które w dużym stopniu wykorzystywane jest do zaspokojenia konsumpcji. W przypadku rozwiązań stosowanych w Polsce przyjęty system wdrażania funduszy strukturalnych ma poważne implikacje dla stanu finansów publicznych.

\section{Financing operation programs in Poland - implications for the public finance}

The article is devoted to the issue of financing of operational programs implemented in Poland in the European Union's financial perspectives 2000-2006 and 2007-2013. Polish membership in the European Union gives the opportunity to obtain additional funds but the possibility of absorption involves costs which Poland has to bear. The author attempts to assess the way in which Poland's adopted systems for operational programs implemented with the participation of EU structural funds influenced the state of the public finances. System solutions used in Poland have implications for two key measures of the state of public finances such that is public debt and budget deficit.

59 A. Wernik, Finanse publiczne, PWE, Warszawa 2007, s. 90; zob. P. Horsman, Inflation in the Twentieth Century: Evidence from Europe and North America, St. Martin`s Press Inc., New York 1988; M. Parkin, Domestic Monetary, Institutions and Deficits, Basil Blackwall, Oxford-New York 1987, s. 310-337; R. Dornbusch, Dollars, Debts, and Deficitis, Leuven University Press, Leuven 1986, s. 184-185; T.J. Stargent, N. Wallace, Some Unpleasant Monetarist Arithmetic, Federal Reserve Bank of Minneapolis, „Quarterly Review” 1981, s. 1-17; R. Heilbroner, P. Bernstein, The Debt and The Deficiti, W.W. Norton and Comp., New York 1989, s. 9-10.

${ }^{60} \mathrm{~K}$. Żukrowska, Rola organizacji międzynarodowych $w$ transformacji krajów postkomunistycznych, w: Transformacja - Integracja - Globalizacja, red. S. Miklaszewski, Instytut Studiów Strategicznych, Kraków 2003, s. 122; zob. P. Behrens, M. Smyrl, A Conflict of Rationalities: EU Regional Policy and the Single Market, ,Journal of European Public Policy” Nr 6 (3), 1999, s. 423-425; S. Ederveen, L.F.H. de Groot, R. Nahius, Fertile soil for Structural Fonds? A panel data analysis of the conditional effectiveness of European cohesion Policy, Tinbergen Institute Discussion Paper TI 2002-096/3, Amsterdam-Rotterdam 2002, s. 2; J. Taylor, C. Wren, UK regional Policy, ,Journal of Regional Studies Association” Nr 3, 1997. 


\section{Le financement des programmes opérationnels en Pologne - implications pour les finances publiques}

Larticle aborde le problème du financement des programmes opérationnels mis en œuvre en Pologne dans les perspectives financières de l'Union européenne 2000-2006 et 2007-2013. Ladhésion de la Pologne à l'Union européenne donne la possibilité d’obtenir des fonds supplémentaires, mais la possibilité d’absorption implique des coûts qui doivent être portés par la Pologne. Lauteur tente dévaluer l'impact des systèmes adoptés par la Pologne pour les programmes opérationnels, mis en œuvre grâce à l'utilisation des fonds structurels européens, sur létat des finances publiques. Les solutions adoptées en Pologne influencent deux indicateurs clés des finances publiques tels que la dette publique et le déficit budgétaire. 